\title{
FANUC CNC MACHINE DAMAGE ANALYSIS USING THE PDCA CYCLE AND KAIZEN IMPLEMENTATION EFFORT IN INCREASING SKILL UP OPERATOR PERFORMANCE IN PT YPMI
}

\author{
Muhammad Ihsan \\ Mercu Buana University, Indonesia \\ E-mail: ihfah2822@gmail.com \\ Rofiatul Hasanah \\ Mercu Buana University, Indonesia \\ E-mail: ofii.math@gmail.com \\ Humiras Hardi Purba \\ Mercu Buana University, Indonesia \\ E-mail: hardipurba@yahoo.com
}

Submission: 15/12/2016

Revision: 28/12/2016

Accept: 28/05/2018

\section{ABSTRACT}

This study aimed to analyze the damage to the machine, look for the biggest trouble factor happen and the most important is the effect of the application of the concept of kaizen to skill up the performance of operators in $\mathrm{CW}$ machining maintenance division. In the analysis and handling of an engine failure, the authors use PDCA cycle (Plan, Do, Check, Action) and the application of kaizen to analyze it. From finding the highest cause of trouble that will be made the theme of improvement by collecting data on the check sheet engine trouble and Pareto diagram, analysis of existing conditions using $5 \mathrm{~W} 2 \mathrm{H}$, causal analysis the occurrence of engine trouble using the fishbone chart, using the concept of kaizen, evaluation of the results, up to standardization and follow-up. From the analysis of damage to the machine and application FANUC machine kaizen concept, showed a decrease in engine trouble and the increase in skill up performance operator significantly, which is certainly very good impact in terms of engine performance. Of course the result is also impact both on the quality of the product that will be used by the customer 
Keywords: Downtime, PDCA, CNC, Trouble, Kaizen

\section{INTRODUCTION}

Along with the rapid development of the world industry resulted in fierce competition, especially in the automotive industry, which requires the industry players do new innovations to produce products are targeted, high quality, and at competitive prices. these demands causing the industry to think hard to try to make it happen.

Various methods are used ranging from good customer service and fast response, delivery time is right, optimization of product functionality, maintain the performance/condition of the engine, until the adoption of new technologies. PT. Yamaha Motor Parts Manufacturing Indonesia as a company engaged in the automotive industry, one of which produces Casting Wheel, the wheels are used on motorcycles.

The process of making the casting wheel at PT. YPMI must through several stages of the process, one of which is the machining process. There are several factors that can affects the quality of the machining of the casting wheel I including raw materials and the condition of the engine.

That Fanuc machine robodrill $\alpha-T 14 f e$ can perform machining processes on the casting wheel with quality products and good quality, it takes a good machining process in a manner appropriate work instruction procedures work (IK) and a performance or reliability of the machine should be good anyway.

Event production process that will either support the achievement of optimum productivity. But they often appear obstacles one of them caused by the flow machines use less than the maximum in result damages are still common.

Of the many factors affecting the maximum use of the machine due to lack of damage that occurs, we cannot finish overall with the same time. For that we specify the type of engine damage that is the highest of the data obtained to look for the cause and prevention of the problem. 
DOI: 10.14807/ijmp.v10i1.590

\section{LITERATURE REVIEW}

\subsection{PDCA Cycle}

PDCA cycle is commonly used to test and implement changes to improve the performance of a product, a process or a system in the future.

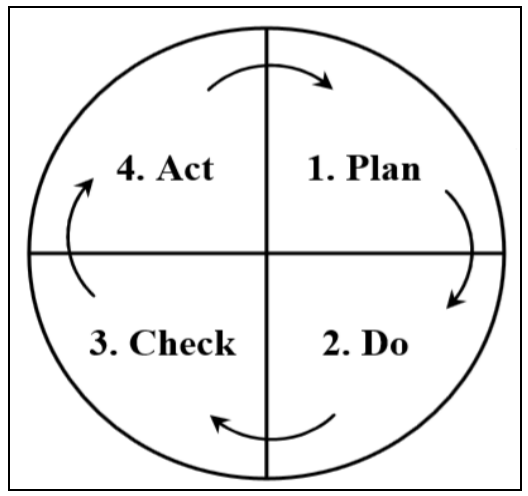

Figure 1: PDCA cycle

Source: Chase, Aqilano and Jacobs (2001)

Explanation of the stages in the PDCA cycle is as follows (NASUTION, 2005): Explanation of the stages in the PDCA cycle is as follows:

(i) Develop a plan (Plan), These include planning specification, set of specifications or standards of good quality, give understanding to subordinate the importance of product quality, the quality control is done CONSEQUENTIAL continuous and sustainable,

(ii) Implementing the plan (Do), plans have been drawn up implemented gradually, starting from small scale and evenly distribution of tasks in accordance with the capacity and capability of each personnel. Over in implementing the plan should be carried out control, which is to strive for the whole plan to be implemented in the best possible target can be achieved,

(iii) Checking or research outcomes (check), check or examine referring to the determination of whether implementation is on track, according to the plan and monitor progress planned improvements. Comparing the quality of production with the standards set, based on the research data showed the failure and then analyzed the causes of failure,

(iv) Perform if necessary adjustment measures (Action), planning specification, set of specifications or standards good quality, give insight to subordinate 
the importance of product quality, control quality is done continuously and sustainably.

\subsection{DELTA Method (Eight Steps, Seven Tools)}

According to Vincent Gaspersz (TOPS: Team Oriented Problem Solving, 2007), eight steps and seventool in the solution of problems that have been commonly known quality is very useful for beginners who are involvedin the process of performance improvement of quality and productivity of the company. Among them are 8 stepsis :

\subsubsection{Defining Problem and Determining Theme of Quality Improvement}

In the field of quality, the problem is the gap (gap) between the output of the process now and customer needs, both internal customers (the following process in SIPOC: Suppliers-Inputs-Processes-Outputs-Customers) and external customers (customer needs). Quality improvement should be related to the theme directly with quality problems encountered in the working environment of their respective companies. When identifying and selecting issues, quality improvement team (Quality Improvement Team) must develop a problem statement that is clearly understood by all members of the team.

\subsubsection{Looking All The Possible Causes}

Quality improvement teams should identify all possible causes lead problems that have been identified in Step 1 above. Step 2 includes the collection and organizing data to document the causes of the problem. The causes of the problem which is probably derived from the controllable factors (7M: Manpower, Methods, Materials, Machines, Mother Nature or Media (Working Environment), Motivation and Money) and causes can expected or predictable (predictable causes) sourced from uncontrollable factors.

\subsubsection{Analyzing the Root Cause of the Problem}

The first sign of a problem is a symptom (symptoms) and not the cause (causes). Therefore the team improving the quality needs to understand what is referred to as: the symptoms (symptoms), causes (causes), and root causes (root causes). 
Asking why several times using a why-why diagram will directed us to get to the root cause of the problem, so that the appropriate action at the root cause problems are found it will eliminate the problem. The root causes of problems found it, then grouped into factor 7M (Manpower, Machines, Methods, Materials, Mother Nature or Media, Motivation, Money).

\subsubsection{Planning a Corrective Action}

Quality problem solution plan should focus on measures to eliminate the root the cause of the problem that is within the scope of responsibilities of the department within the organization (controllable causes), and anticipating the causes uncontrolled but unpredictable (uncontrollable but predictable causes).

\subsubsection{Improvement Implementation}

Carrying out repairs means the implementation of permanent corrective actions are in dire need commitment of management and employees as well as the total participation to jointly eliminate the root the causes of quality problems that have been identified in step three above. Data recording quality also be done during the implementation stage as well as the need to identify the cause of the event irregularities in the implementation phase of this permanent corrective action.

\subsubsection{Studying Result of Improvement}

After the implementation of quality improvement projects over a certain period by a team improvement quality, usually 3-6 months, necessary to study and evaluation based on data collected during improving the quality of the project implementation phase was to determine whether the types of problems that exist have been lost or less, which shows that quality improvement projects that are truly effective and efficient.

\subsubsection{Standardizing Solutions and Best Practices}

The results were satisfactory from the permanent corrective action or solution to the problem through the project quality improvement should be standardized, and thus achieve continuous improvement in kind other issues raised following the Eightfold Path.

\subsubsection{Make a Final Report and Determining Next Plan of Quality Improvement}


INDEPENDENT JOURNAL OF MANAGEMENT \& PRODUCTION (IJM\&P)

http://www.ijmp.jor.br

v. 10, n. 1, January - February 2019

ISSN: 2236-269X

DOI: 10.14807/ijmp.v10i1.590

All 8 steps outlined above may be organized into a cycle of Deming (PDCA: Plan, Do, Check, Act) or into the cycle of DMAIC (Define, Measure, Analyze, Improve, and Control)a methodological approach to the problem solution in Six Sigma projects.

\subsection{KAIZEN Philosophy}

Kaizen is derived from the word meaning improvement and ZENKAI means either. Kaizen is defined as an improvement continuously (continuous improvement). Feature key kaizen management, among others, more attention to the process and not the result, cross-functional management and using quality circles and other equipment for supporting continuous improvement (CANE, 1998).

For some people may be familiar with the word Kaizen (read: kai-zinc). Literally $\mathrm{Kai}=$ change and Zen $=$ better. In a simple sense Kaizen is a continuous improvement effort to be better than the present conditions. There are also people who have called Kaizen Teian which means: "Kaizen" means "continuous improvement", while "teian" means "system". So, Kaizen Teian means a comprehensive enterprise system is done in order continuous improvement striving to achieve better conditions than today, so as to bring a new breath in every company or organization.

In its application within the company, including the definition Kaizen continuous improvement involving all workers, both top-level management to lower levels of management (TAKEDA, 2006). Kaizen or continuous improvement is always in conjunction with the Total Quality Management (TQM).

Even before the TQM philosophy is carried out or before the quality system can implemented in a company then this philosophy will be implemented so that improvements continuous (Just in time) this is a business that is attached to the TQM philosophy itself.

So that could Kaizen also a unified view of a comprehensive and integrated characterized customer oriented, thorough quality control (Total Quality Management), robotics, quality control, system advice, automation, discipline at work, maintenance of productivity, Kanban, refinement and improvement of quality, timely, seamless, small group activities, cooperative relationships between managers and employees and new product development. 
DOI: 10.14807/ijmp.v10i1.590

\section{METHODOLOGY}

In conducting the analysis and search for overcoming the problem of engine damage, and to investigate increase skill up maintenance, the authors performed the steps below :

a) Collect data daily engine trouble over a period of one year, using a check sheet.

b) Analyze the data check sheet into Histogram to determine what kind of trouble most high in a period of 1 year.

c) Knowing the kind of trouble that priority will be followed up to do improvement/kaizen, using Pareto Diagram.

d) Implementation of the system within the PDCA cycle DELTA contained seven tools, for facilitate troubleshooting in engine damage.

e) Review basic maintenance skills up before and after repair within one year.

All of the steps are carried out above, the authors found an increased skill up maintenance significantly. This course will be a major influence on performance motivation maintenance with added kaizen reward.

\section{RESULTS AND DISCUSSION}

\subsection{Collecting data using Check sheet}

Note that the first day of production, there can be not only one type(engine trouble), but can be more than one kind. Therefore, the type of damage recorded by the maintenance part is the most dominant type of damage. Data taken from the data damage that occurred in January 2013 until December 2013. The following is data about engine damage Fanuc robodrill at the Dept. 3 Production Machining Casting Wheel PT.YPMI.

Table 1: Unit in minutes

\begin{tabular}{|l|r|r|r|r|r|r|r|r|r|r|r|r|r|}
\hline \multicolumn{1}{|c|}{ Item Trouble } & Jan & Feb & Mar & Apr & May & Jun & Jul & Aug & Sep & Oct & Nov & Dec & Total \\
\hline Door & 446 & 90 & 372 & 301 & 120 & 366 & 38 & 21 & 129 & 0 & 130 & 153 & 2166 \\
\hline Coolant Device & 30 & 20 & 84 & 51 & 0 & 0 & 0 & 170 & 50 & 85 & 80 & 60 & 630 \\
\hline Spindle & 0 & 109 & 290 & 108 & 160 & 60 & 270 & 0 & 25 & 240 & 328 & 305 & 1895 \\
\hline Moving Axis & 0 & 86 & 42 & 0 & 12 & 0 & 100 & 0 & 0 & 395 & 0 & 260 & 895 \\
\hline Magazine & 65 & 145 & 0 & 0 & 0 & 0 & 0 & 0 & 15 & 50 & 295 & 165 & 735 \\
\hline Control panel & 0 & 0 & 0 & 0 & 0 & 240 & 45 & 0 & 50 & 45 & 0 & 0 & 380 \\
\hline Operating panel & 54 & 0 & 20 & 149 & 110 & 99 & 155 & 30 & 0 & 300 & 90 & 0 & 1007 \\
\hline Pneumatic Device & 0 & 5 & 0 & 0 & 0 & 0 & 0 & 0 & 0 & 0 & 10 & 25 & 40 \\
\hline Other & 10 & 11 & 0 & 0 & 0 & 0 & 57 & 42 & 20 & 5 & 200 & 0 & 345 \\
\hline
\end{tabular}


INDEPENDENT JOURNAL OF MANAGEMENT \& PRODUCTION (IJM\&P)

http://www.ijmp.jor.br

v. 10, n. 1, January - February 2019

ISSN: 2236-269X

DOI: 10.14807/ijmp.v10i1.590

\subsection{Analyzing data using Histogram}

To make it easier to see more clearly the trouble that occurs in accordance with the above table, then the next step is to create a histogram. The trouble Data presented in graphical form be am divided by type of machinery spare parts available

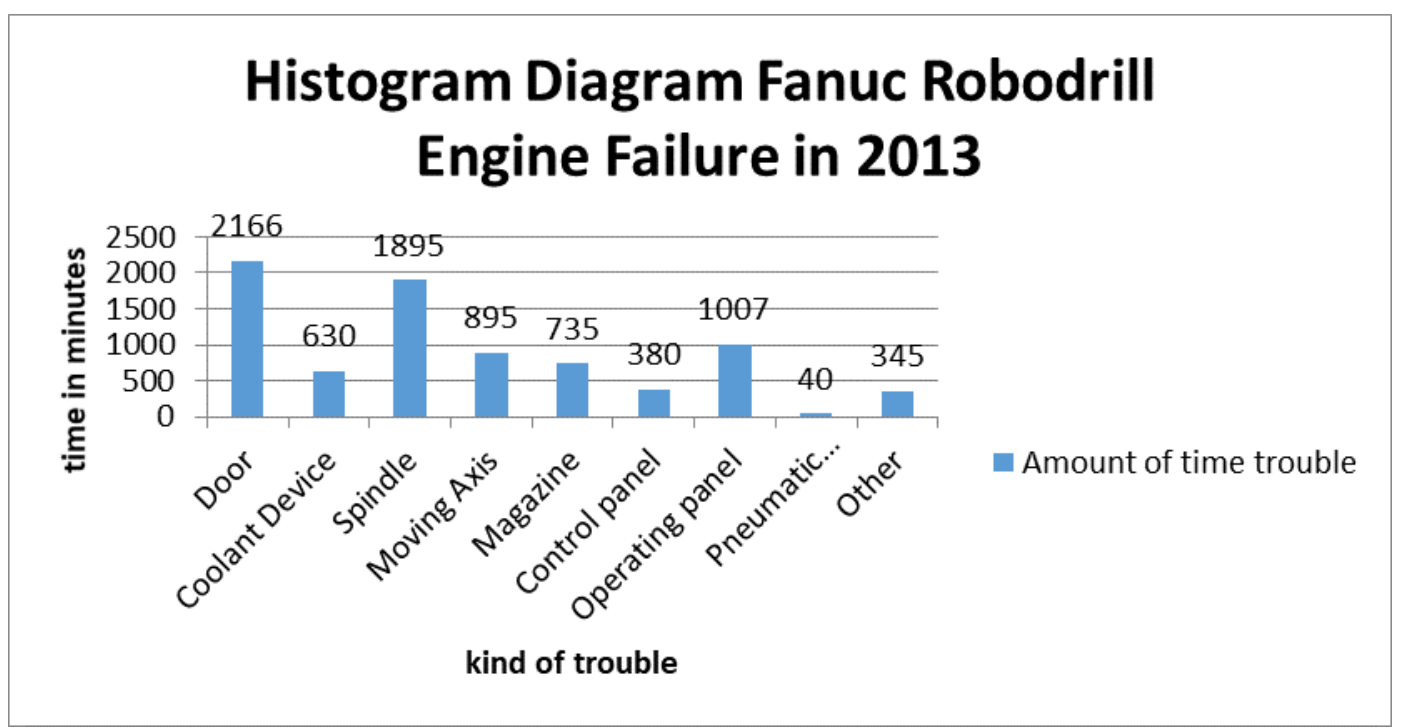

Figure 2: Histogram Diagram FANUC Robodrill

\subsection{Determine improvement priorities (using Pareto Diagram)}

By using Pareto diagram, can be seen where the dominant trouble so it can identifies priorities for solving the problems within a year period. Pareto diagram is a diagram that used to identify, sort and work to eliminate damage to the machine permanent. With this diagram, it can be seen the kind of damage that the most dominant machine on production processes during 2013.

Table 2: Percentage of Engine Failure Group

\begin{tabular}{lllll}
\hline Item Trouble & $\begin{array}{l}\text { Amount } \\
\text { of time } \\
\text { trouble }\end{array}$ & Percentage & $\begin{array}{l}\text { Cumulative } \\
\text { Percentage }\end{array}$ & $\begin{array}{l}\text { Description } \\
\text { Cumulative } \\
\text { Summation }\end{array}$ \\
\hline Door & 2166 & $26.76 \%$ & $26.76 \%$ & $26.80 \%$ \\
\hline Coolant Device & 630 & $23.42 \%$ & $50.18 \%$ & $26.8 \%+23.42 \%$ \\
\hline Spindle & 1895 & $12.44 \%$ & $62.62 \%$ & \\
\hline Moving Axis & 895 & $11.06 \%$ & $73.68 \%$ & \\
\hline Magazine & 735 & $9.08 \%$ & $82.76 \%$ & \\
\hline Control panel & 380 & $7.78 \%$ & $90.54 \%$ & \\
\hline Operating panel & 1007 & $4.70 \%$ & $95.24 \%$ & \\
\hline Pneumatic Device & 40 & $4.27 \%$ & $99.51 \%$ & \\
\hline Other & 345 & $0.49 \%$ & $100.00 \%$ & \\
\hline Total & 8093 & $100 \%$ & & \\
\hline
\end{tabular}


Based on the above data it can be arranged a Pareto Diagram as shown in the picture below :

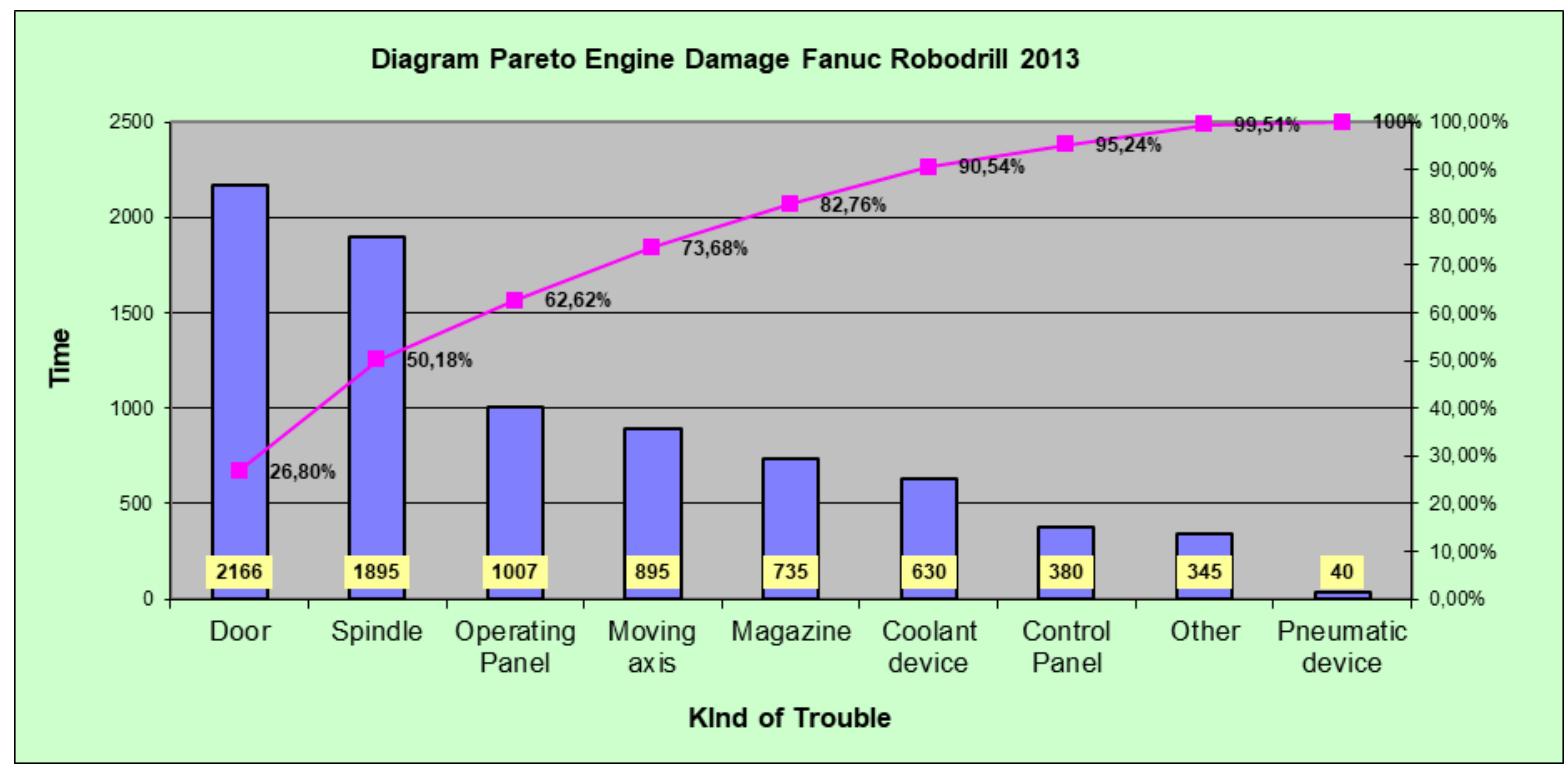

Figure 3: Diagram Pareto Engine Damage

From the observation can be seen that almost $70 \%$ of engine failure that occurred on Fanuc machine RoboDrill in 2013 was dominated by three types of damage, namely the trouble 'Door' with percentage of $26,76 \%$, the group trouble 'splinde' amounted to $23,42 \%$ and the group of trouble 'operation panel' $12,44 \%$ of the total number of trouble in 2013.

\subsection{Implementation of the application of methods DELTA in PDCA cycle for}

\section{Troubleshooting}

\subsubsection{Plan}

Step 1: Defining Problem and Determining Theme of Quality Improvement

With the discovery of a class of the most highest trouble (trouble the 'Door') with using the tools of the check sheet, histogram, and Pareto diagram, the researchers further analyzed deeper trouble group "door" by selecting the most dominant trouble occurred in 2013.

Of the few phenomena that damage occurs on the door of the machine, there is a kind of trouble that is very dominate in 2013 . That trouble "Lever Door not return to its original position". 
ISSN: 2236-269X

DOI: 10.14807/ijmp.v10i1.590

Here is an example of the daily check sheet in which there are examples of most engine damage dominant place, namely: "Door Lever Not back into position first," and the data collected during the In 2013 the group door.

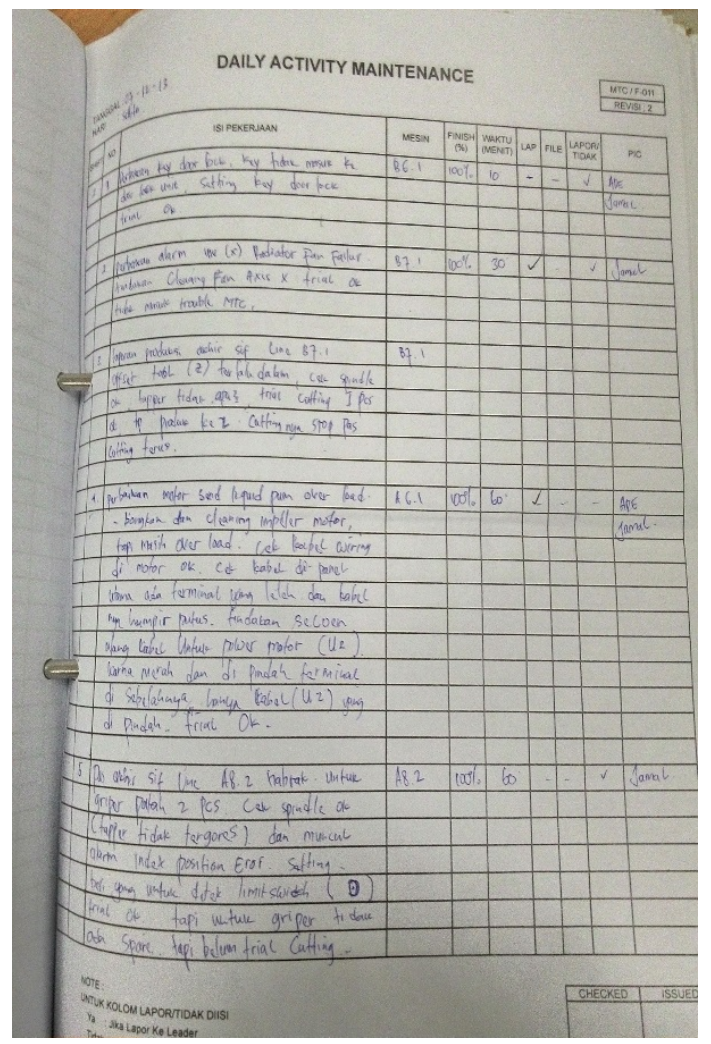

Figure 4: Example of the daily check sheet

With the daily check sheet, then researchers collected data on all kinds of trouble group "Door" into a table. Below is a table of the damage that occurred in the group "door".

Table 3: Trouble Door 2013

\begin{tabular}{|c|c|c|c|c|c|c|c|c|c|c|c|c|c|}
\hline Item Trouble & Jan & Feb & Mar & Apr & May & Jun & Jul & Aug & Sep & Oct & Nov & Dec & Total \\
\hline $\begin{array}{l}\text { Lever door doesn't return to } \\
\text { original position }\end{array}$ & 40 & 80 & 68 & 90 & 85 & 30 & 91 & 35 & 50 & 89 & 112 & 124 & 894 \\
\hline $\begin{array}{l}\text { Roller plummeted due to } \\
\text { hampered scrap }\end{array}$ & 10 & 20 & 21 & 30 & 0 & 0 & 0 & 21 & 50 & 55 & 40 & 42 & 289 \\
\hline $\begin{array}{l}\text { Leave the door cracked and } \\
\text { leaking }\end{array}$ & 20 & 0 & 25 & 59 & 90 & 47 & 38 & 0 & 25 & 0 & 30 & 50 & 384 \\
\hline Rell doors off & 0 & 23 & 10 & 0 & 12 & 0 & 40 & 0 & 0 & 15 & 0 & 32 & 132 \\
\hline $\begin{array}{l}\text { Support locking off the } \\
\text { glass }\end{array}$ & 10 & 35 & 0 & 0 & 0 & 0 & 0 & 0 & 15 & 45 & 23 & 40 & 168 \\
\hline $\begin{array}{l}\text { Drag door movement I } \\
\text { standstill }\end{array}$ & 25 & 0 & 0 & 0 & 0 & 20 & 45 & 0 & 25 & 5 & 0 & 0 & 120 \\
\hline $\begin{array}{l}\text { Key door didn't get into the } \\
\text { door lock }\end{array}$ & 14 & 0 & 0 & 15 & 30 & 30 & 10 & 30 & 0 & 0 & 0 & 0 & 129 \\
\hline Handle door broken & 10 & 5 & 0 & 0 & 0 & 0 & 0 & 0 & 0 & 0 & 10 & 25 & 50 \\
\hline Total & 129 & 163 & 124 & 194 & 217 & 127 & 224 & 86 & 165 & 209 & 215 & 313 & 2166 \\
\hline
\end{tabular}


INDEPENDENT JOURNAL OF MANAGEMENT \& PRODUCTION (IJM\&P)

http://www.ijmp.jor.br

v. 10, n. 1, January - February 2019

ISSN: 2236-269X

DOI: 10.14807/ijmp.v10i1.590

So that researchers know the kind of trouble that is most dominant in the group "door", the investigator using Pareto diagram to prove what kind of trouble most dominant happened to group trouble "door" in the period of 2013. The next step is the data in Table 4 should sorted by the amount of damage, ranging from the largest to the smallest and made cumulative percentage. The cumulative percentage is useful to state how differences infrequency of occurrence among several issues are dominant.

Table 4: Should sorted by the amount of damage

\begin{tabular}{lllll}
\hline Item Trouble & $\begin{array}{l}\text { Total } \\
\text { (unit in } \\
\text { minute) }\end{array}$ & Percentage & $\begin{array}{l}\text { Cumulative } \\
\text { Percentage }\end{array}$ & $\begin{array}{l}\text { Description } \\
\text { Cumulative } \\
\text { Summation }\end{array}$ \\
\hline $\begin{array}{l}\text { Lever door doesn't return to } \\
\text { original position }\end{array}$ & 894 & $41.27 \%$ & $41.27 \%$ & $41.27 \%$ \\
\hline $\begin{array}{l}\text { Roller plummeted due to } \\
\text { hampered scrap }\end{array}$ & 384 & $17.73 \%$ & $59.00 \%$ & $41.27 \%+17.72 \%$ \\
\hline $\begin{array}{l}\text { Leave the door cracked and } \\
\text { leaking }\end{array}$ & 289 & $13.35 \%$ & $72.35 \%$ & \\
\hline $\begin{array}{l}\text { Rell doors off } \\
\text { Support locking off the glass }\end{array}$ & 132 & $6.10 \%$ & $86.21 \%$ & \\
\hline $\begin{array}{l}\text { Drag door movement } \\
\text { standstill }\end{array}$ & 129 & $5.95 \%$ & $92.16 \%$ & \\
\hline $\begin{array}{l}\text { Key door didn't get into the } \\
\text { door lock }\end{array}$ & 120 & $5.54 \%$ & $97.70 \%$ & \\
\hline Handle door broken & 50 & $2.30 \%$ & $100.00 \%$ & \\
\hline Total & 2166 & $100 \%$ & & \\
\hline
\end{tabular}

Based on the above data it can be arranged a Pareto Diagram as shown in the following figure

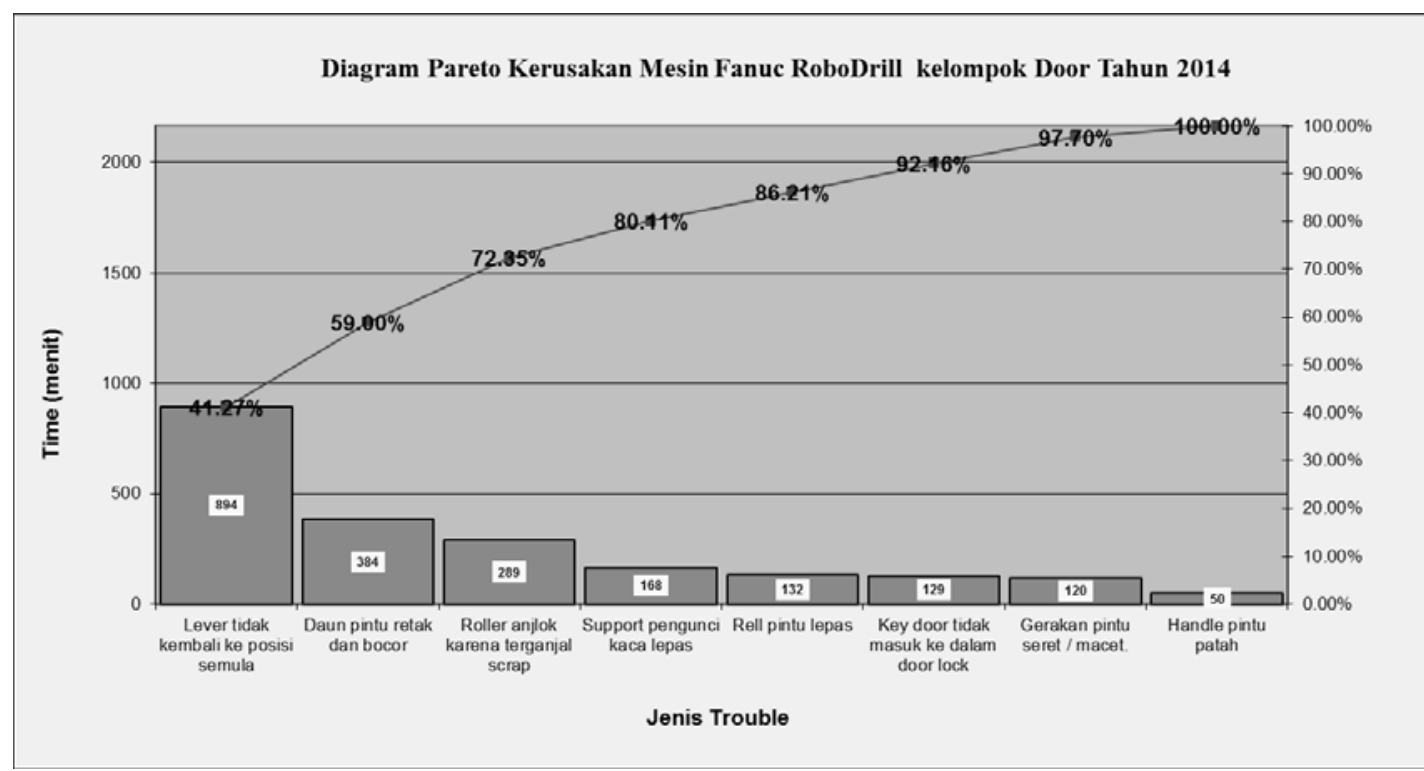

Figure 5: Diagram Pareto Kerusakan Mesin 
INDEPENDENT JOURNAL OF MANAGEMENT \& PRODUCTION (IJM\&P)

http://www.ijmp.jor.br

v. 10, n. 1, January - February 2019

ISSN: 2236-269X

DOI: 10.14807/ijmp.v10i1.590

\section{Step 2 : Search for All Causes of Breakdown 9using tools Fishbone Chart)}

Furthermore, researchers perform data processing using tools fishbone diagram (Fish Bone Chart) to locate all causes - causes that resulted in damage "lever door not back to its original position" occurs. Below is a diagram fishbone I Fish Bone Chart result of data processing based on the data - field data as well as interviews to operators production and leader production who was in the field when the damage occurred, the researchers get.

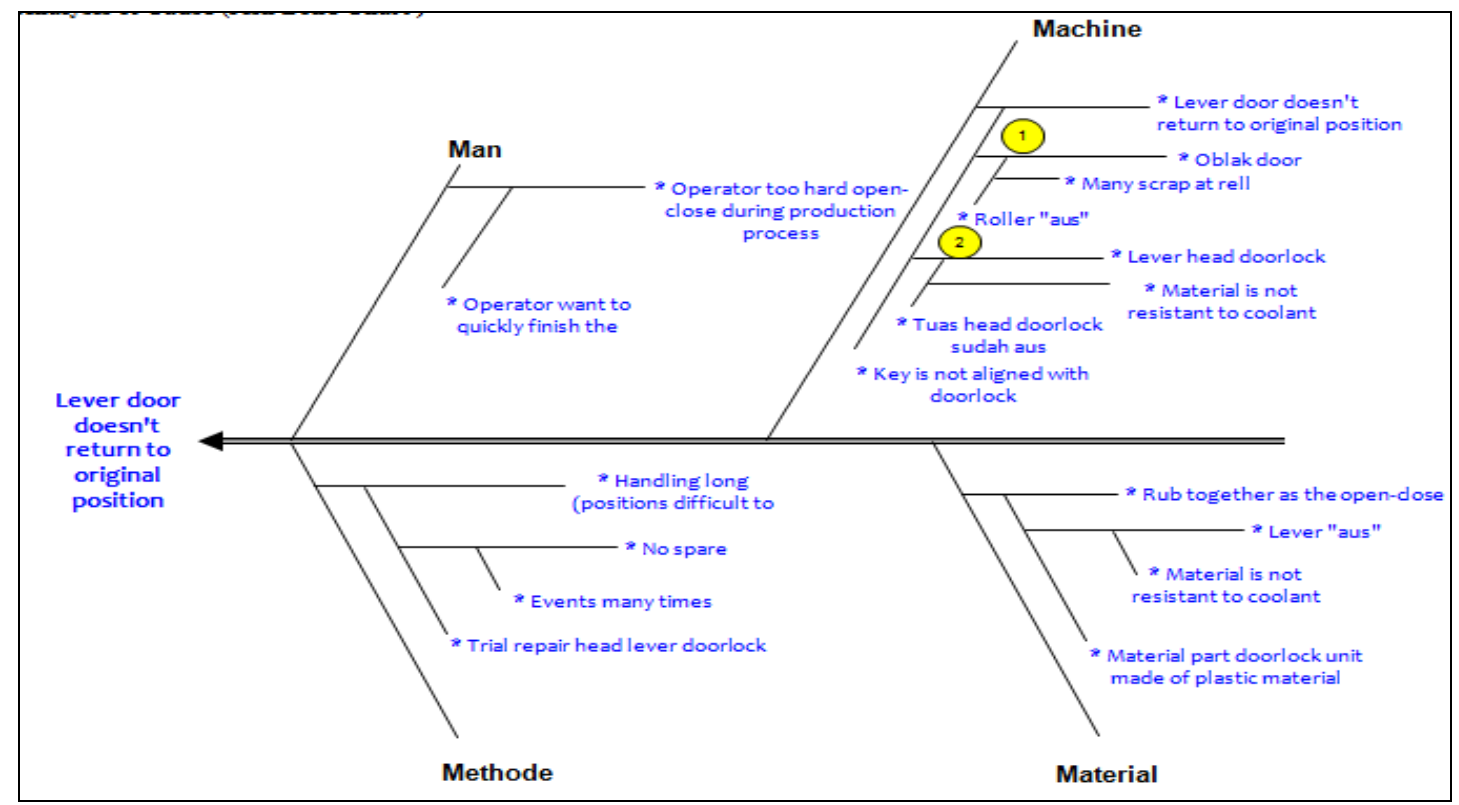

Figure 6: Analysis of Cause (Fish Bone Chart)

Causal diagram shows the relationship between the problems faced by possible reasons and factors that influence it. The analysis of the causes of group Door trouble with trouble name "Door Lever does not return to its original position" is as follows:

\subsubsection{Human Factors}

When the operator opens the door after the cutting process is finished, the operator opens the door in a hurry- Hurry or rush - rush. Resulting in head lever door lock components made of plastic, experienced a pulling force is too large. So that the door lock lever head of wear on parts head. Similarly, in closing the door. Head door lock lever to clash very hard when there is contact with the key switch made of iron plate. Operator to open - close the door with haste - haste aims to speed up the time target.

\subsubsection{Machine Factors}


INDEPENDENT JOURNAL OF MANAGEMENT \& PRODUCTION (IJM\&P)

http://www.ijmp.jor.br

v. 10, n. 1, January - February 2019

ISSN: 2236-269X

DOI: 10.14807/ijmp.v10i1.590

Key door position switch experiencing tilt due to concussion that occurs when the door is shut down. Movement of the door into drag (gap) for roller doors wear out. While the cause of roller experiencing wear, is because a lot of scrap coming into the roller area. So that the roller is made of nylon rubbing against the incoming scrap. Head lever door lock made of plastic experience wear and tear caused concussion with key switch made of iron plate. This is what causes head lever door lock lever does not return to its original position, after the door is opened.

\subsubsection{Method Factors}

Repair trouble lever door lock does not return to its normal position requires a long time, because the position of the door lock unit itself is difficult to reach under normal circumstances and on a narrow position. Event The trouble is very often the case with the amount of time 2166 minutes per year. Trouble is a kind trouble highest compared with other kinds of trouble.

With a high-intensity, kind of trouble is also spending a lot of the same types of parts for handle such improvements. So the company has experienced indent part for part types door lock unit.

\section{Step 3 : Analyze Root Cause Problems}

Researchers analyzed the causes of damage to the machine and material factors. In the machinery and material factors. There are a number of causes of damage are closely linked and often happens, the lever wear cause liver cannot return to its original position.

While the cause why lever can be fast suffering from wear, it happened because the lever is made of plastic material that can be easily damaged if experience impact or friction with objects harder material than on the lever (iron).

Even more during the process of cutting evaporation coolant vapor is then attached to the components door lock unit including a head lever door lock. Next image detail analysis of the causes of damage "lever door does not return to its original position ".

Below is a picture where the position is at the door lock robodrill Fanuc machines. Position door lock difficult to reach by the operator (the necessary tools to achieve them) and on the engine is very narrow, being one of the causes why the 
INDEPENDENT JOURNAL OF MANAGEMENT \& PRODUCTION (IJM\&P)

http://www.ijmp.jor.br

v. 10, n. 1, January - February 2019

ISSN: 2236-269X

DOI: 10.14807/ijmp.v10i1.590

length of time needed to make repairs in case of trouble "lever door lock does not return to its original position".

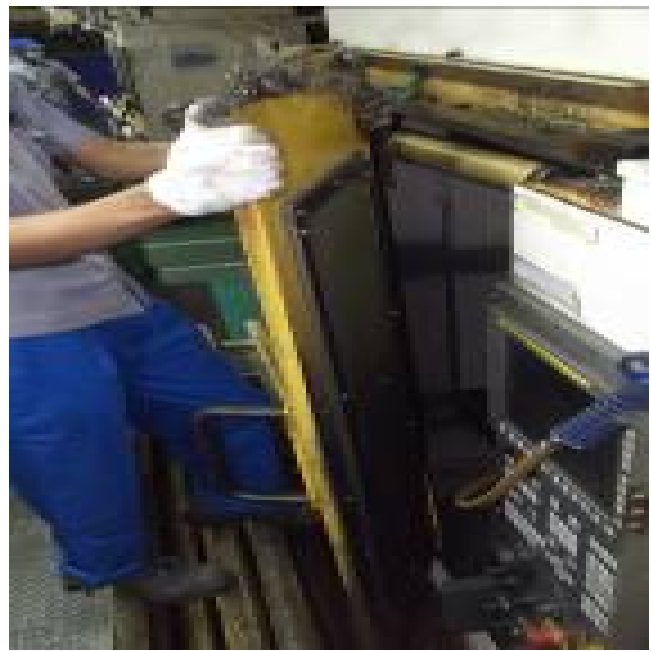

Figure 7: lever door lock does not return to its original position

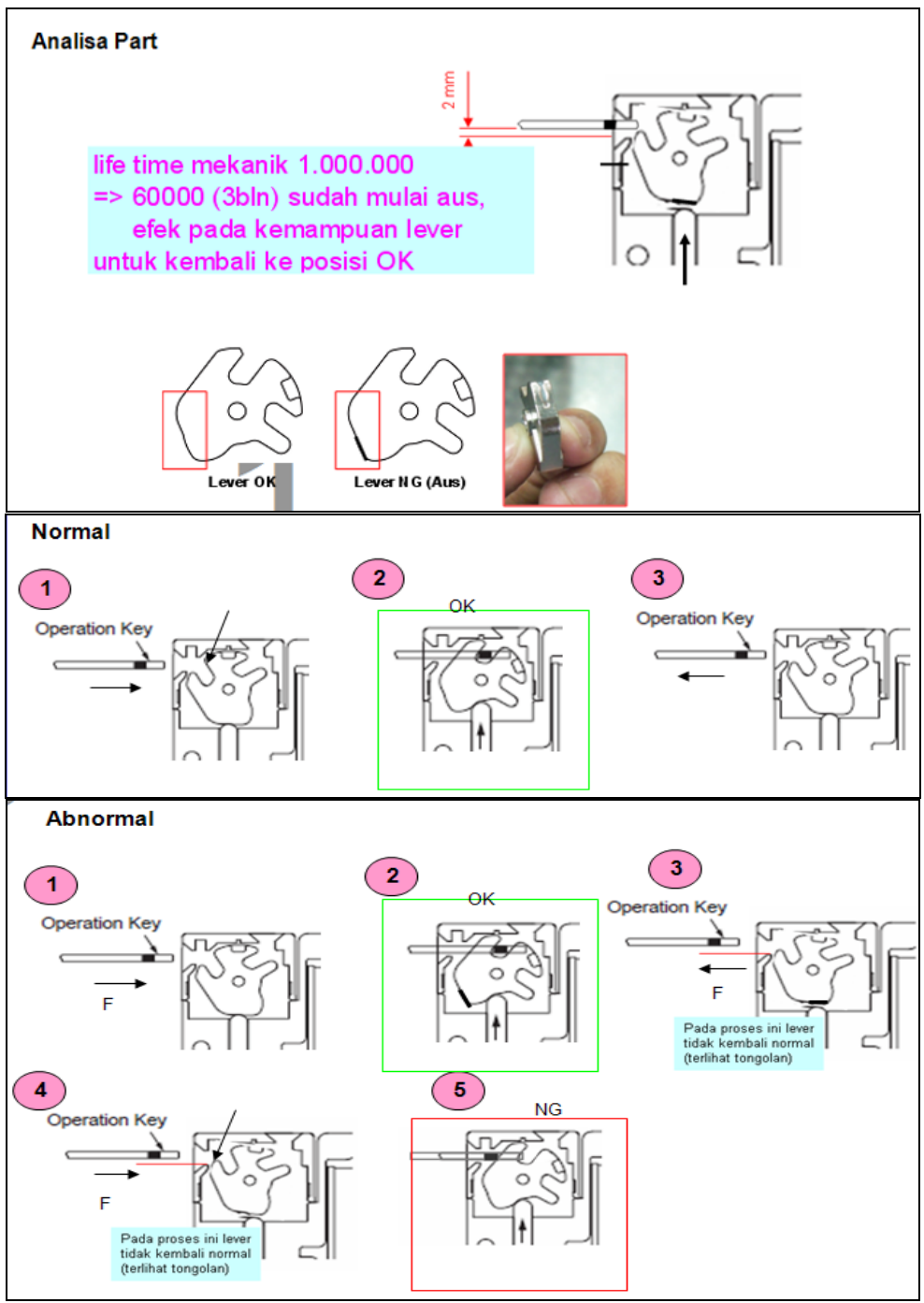


ISSN: 2236-269X

DOI: 10.14807/ijmp.v10i1.590

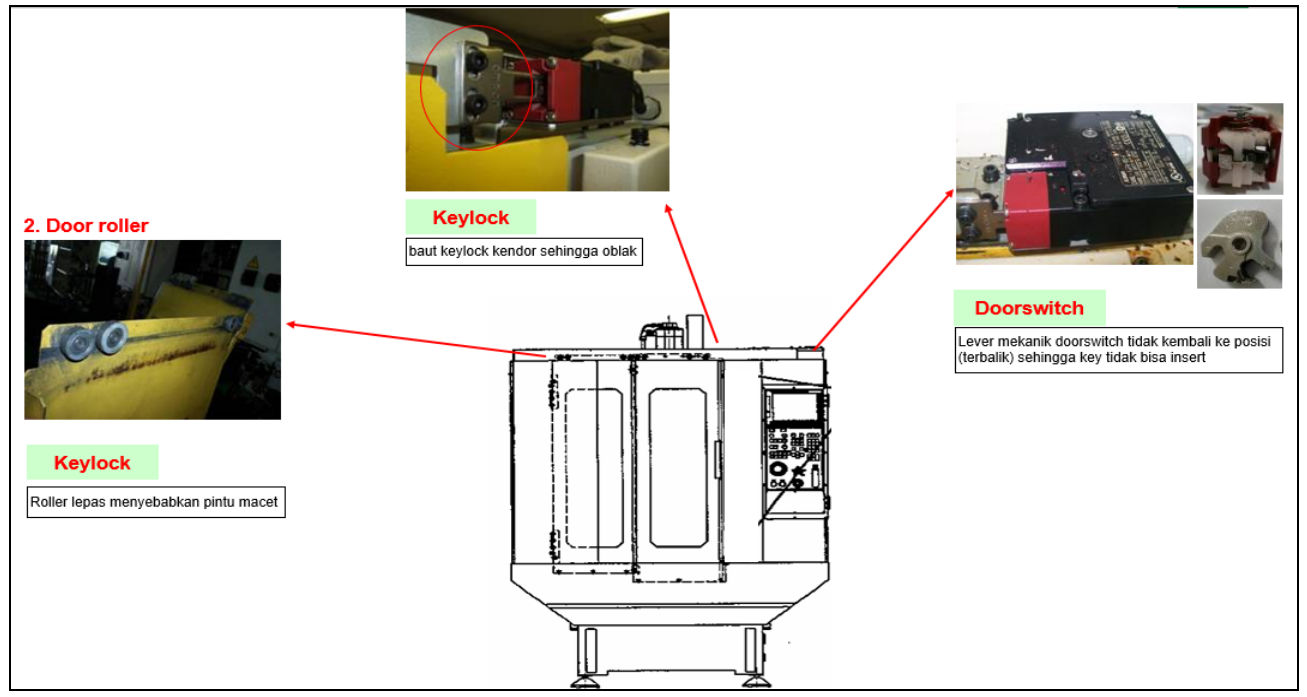

Figure 8: Analysis on the engine part

Step 4 : Corrective Action Plan

After knowing the cause of damage type of machine trouble the 'Door' with the name 'level door does not return to its normal position 'which occurred at PT. YPMI is the most dominant place every month in 2013, then drafted a recommendation or a proposal of corrective actions in general in an effort to reduce the level of damage by making a general schedule retrieval and analysis Cause and Effect with $5 \mathrm{~W} 2 \mathrm{H}$ method as follows:

Table 5: Factor Penyebab

Faktor Penyebab kelompok trouble Door dengan nama trouble "Lever Door tidak kembali ke posisi semula" di cari dengan metode $5 \mathrm{~W} 2 \mathrm{H}$, sebagai berikut :

\begin{tabular}{|c|c|c|c|c|c|c|c|c|c|}
\hline \multirow{2}{*}{ FAKTOR } & \multirow{2}{*}{ No } & \multicolumn{2}{|c|}{$\begin{array}{r}\text { WHAT } \\
\end{array}$} & WHY & WHERE & HOW & WHEN & WHO & HOW MANY \\
\hline & & MASALAH & AKIBAT & KENAPA & DIMANA & PENANGANAN & KAPAN & SIAPA & BIAYA \\
\hline Metode & 1 & $\begin{array}{c}\text { Penanganan Lama } \\
\text { (Posisi sulit di jangkau) }\end{array}$ & & $\begin{array}{l}\text { Belum ada standar } \\
\text { IK (Instruksi Kerja) } \\
\text { yang dipakai dalam } \\
\text { perbaikan }\end{array}$ & Di Mesin & $\begin{array}{c}\text { Di buatkan IK yang } \\
\text { sesuai standart } \\
\text { perbaikan yang } \\
\text { mengutamakan } \\
\text { safety }\end{array}$ & $\begin{array}{l}\text { Secepatnya } \\
\text { (Continue) }\end{array}$ & $\begin{array}{l}\text { Foreman, } \\
\text { Leader, dan } \\
\text { operator } \\
\text { lapangan }\end{array}$ & \\
\hline Mesin & 2 & $\begin{array}{l}\text { Lever Door tidak } \\
\text { kembali ke posisi } \\
\text { normal }\end{array}$ & $\begin{array}{l}\text { Key tidak sejajar } \\
\text { dengan doorlock, }\end{array}$ & 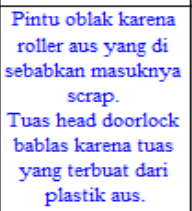 & Di Mesin & $\begin{array}{l}\text { Dibuatkan schedule } \\
5 \text { P setelah proses } \\
\text { produksi selesai ( } \\
\text { tiap akhir shift) }\end{array}$ & $\begin{array}{l}\text { Di Buatkan } \\
\text { Schedule } \\
\text { untuk } \\
\text { setiap } \\
\text { mesin }\end{array}$ & \begin{tabular}{|c} 
Maintenance \\
(Leader \& \\
operator \\
lapangan)
\end{tabular} & \\
\hline Material & 3 & $\begin{array}{l}\text { Tuas head door lock } \\
\text { mudah aus jika } \\
\text { bergesekan saat buka - } \\
\text { tutup }\end{array}$ & $\begin{array}{c}\text { Lever Door tidak } \\
\text { kembali ke posisi } \\
\text { normal dan posisi } \\
\text { key terhadap tuas } \\
\text { head door lock } \\
\text { menjadi miring }\end{array}$ & $\begin{array}{l}\text { Tuas head door } \\
\text { lock terbuat dari } \\
\text { bahan plastik dan } \\
\text { tidak tahan } \\
\text { terhadap coolant } \\
\text { (mudah hancur) }\end{array}$ & Di Mesin & $\begin{array}{c}\text { Penggantian type } \\
\text { jenis door lock unit } \\
\text { menjadi Cylinder } \\
\text { lock yang tebuat dari } \\
\text { bahan alumunium }\end{array}$ & $\begin{array}{l}\text { Di Buatkan } \\
\text { Schedule } \\
\text { untuk } \\
\text { setiap } \\
\text { mesin }\end{array}$ & \begin{tabular}{|c|} 
Maintenance \\
(Leader \& \\
operator \\
lapangan)
\end{tabular} & \\
\hline Manusia & 4 & $\begin{array}{c}\text { Operator terlalu keras } \\
\text { buka-tutup saat proses } \\
\text { produksi }\end{array}$ & $\begin{array}{c}\text { Pergerkan door } \\
\text { menjadi abnormal. } \\
\text { Door lock unit } \\
\text { menjadi cepat } \\
\text { trouble }\end{array}$ & $\begin{array}{c}\text { Operator ingin } \\
\text { cepat selesai target } \\
\text { produksi }\end{array}$ & $\begin{array}{c}\text { Di Dept. } \\
\text { Produksi } 3 \\
\text { Machining } \\
\text { Casting } \\
\text { Wheel }\end{array}$ & $\begin{array}{c}\text { Dilakukan } \\
\text { pendidikan training } \\
\text { tentang perawatan } \\
\text { mesin untuk } \\
\text { pemerataan skill dan } \\
\text { moral operator }\end{array}$ & $\begin{array}{c}\text { Setiap hari } \\
\text { jumat saat } \\
\text { jam } \\
\text { pendidikan } \\
\text { (pukul } \\
16.30-\end{array}$ & $\begin{array}{l}\text { GenFor, } \\
\text { Foreman, } \\
\text { dan leader } \\
\text { Produksi }\end{array}$ & \\
\hline
\end{tabular}

Analysis of causation $5 \mathrm{~W} 2 \mathrm{H}$ trouble group Door cause and effect $5 \mathrm{~W} 2 \mathrm{H}$ trouble group Door 
INDEPENDENT JOURNAL OF MANAGEMENT \& PRODUCTION (IJM\&P)

http://www.ijmp.jor.br

v. 10, n. 1, January - February 2019

ISSN: 2236-269X

DOI: 10.14807/ijmp.v10i1.590

\subsubsection{Do (Implement)}

Step 5 : Implement Improvement with Kaizen Philosophy (Change System)

With reference to the causal analysis by the method of $5 \mathrm{~W} 2 \mathrm{H}$, researchers conducted improvement/Kaizen in trouble "Door Lock" by changing the process of standard door lock system, a material change of door lock which was originally wearing part Omron be door lock unit type cylinder lock with the operation of the mechanical system -pneumatic. The revamped operating system among others is, locking the system which originally uses electrical energy, into pneumatic energy. Type locking material which is generally made of plastic, converted into iron and aluminum materials.

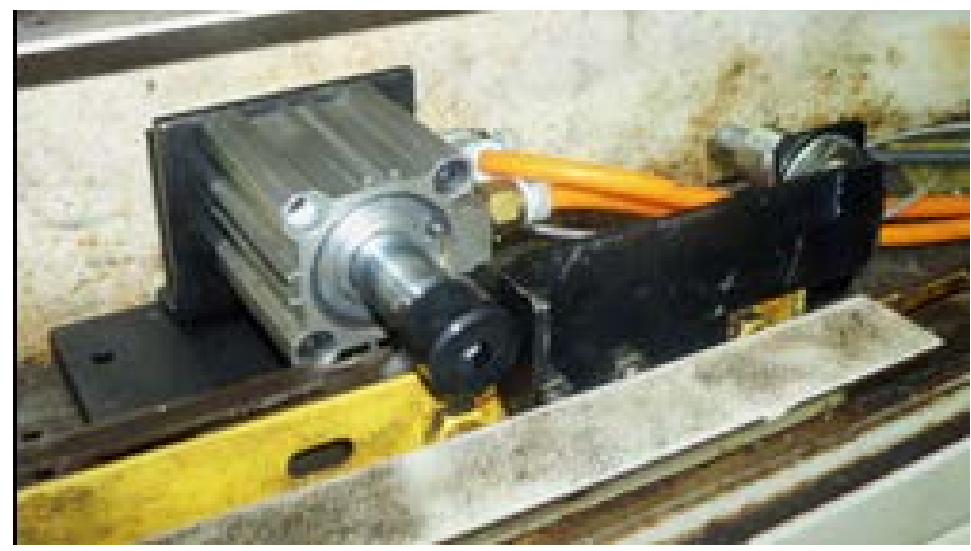

Figure 9. Cylinder Lock Unit

\subsubsection{Check (Studying)}

Step 6 : Study Results - Improved Results

After the improvement in the standardization work system robodrill Fanuc machine at the door, then the researchers analyzed the results of the improvement was done by collecting data damage to the group "Door" from March until the month of December 2014. Below is Table data collection engine failure group type "Door", after doing repairs and improvement in 2014.

Table 6: Trouble Door 2014

\begin{tabular}{|c|c|c|c|c|c|c|c|c|c|c|c|c|c|}
\hline Item Trouble & Jan & Feb & Mar & Apr & May & Jun & Jul & Aug & Sep & Oct & Nov & Dec & Total \\
\hline Alarm Door not lock & 50 & 45 & 20 & 15 & 10 & 0 & 0 & 0 & 0 & 0 & 0 & 0 & 140 \\
\hline $\begin{array}{l}\text { Roller plummeted due to } \\
\text { hampered scrap }\end{array}$ & 10 & 20 & 21 & 30 & 0 & 0 & 0 & 21 & 25 & 0 & 15 & 12 & 154 \\
\hline $\begin{array}{l}\text { Leave the door cracked and } \\
\text { leaking }\end{array}$ & 20 & 0 & 25 & 59 & 90 & 47 & 38 & 0 & 25 & 0 & 30 & 50 & 272 \\
\hline Rell doors off & 0 & 23 & 10 & 0 & 12 & 0 & 20 & 0 & 0 & 15 & 0 & 27 & 107 \\
\hline $\begin{array}{l}\text { Support locking off the } \\
\text { glass }\end{array}$ & 10 & 5 & 15 & 0 & 10 & 0 & 5 & 0 & 15 & 18 & 15 & 12 & 105 \\
\hline
\end{tabular}


INDEPENDENT JOURNAL OF MANAGEMENT \& PRODUCTION (IJM\&P)

http://www.ijmp.jor.br

v. 10, n. 1, January - February 2019

ISSN: 2236-269X

DOI: 10.14807/ijmp.v10i1.590

\begin{tabular}{lllllllllllllll}
\hline $\begin{array}{l}\text { Drag door movement } \\
\text { standstill }\end{array}$ & 10 & 8 & 4 & 8 & 15 & 10 & 5 & 0 & 20 & 5 & 0 & 10 & 95 \\
\hline $\begin{array}{l}\text { Key door didn't get into the } \\
\text { door lock }\end{array}$ & 7 & 0 & 0 & 13 & 9 & 11 & 10 & 15 & 0 & 0 & 5 & 0 & 70 \\
\hline Handle door broken & 10 & 5 & 0 & 0 & 0 & 0 & 5 & 0 & 0 & 0 & 10 & 15 & 45 \\
\hline Total & $\mathbf{1 1 7}$ & $\mathbf{1 0 6}$ & $\mathbf{9 5}$ & $\mathbf{9 6}$ & $\mathbf{7 8}$ & $\mathbf{5 1}$ & $\mathbf{8 5}$ & $\mathbf{3 6}$ & $\mathbf{8 5}$ & $\mathbf{8 8}$ & $\mathbf{4 5}$ & $\mathbf{1 0 6}$ & $\mathbf{9 8 8}$ \\
\hline
\end{tabular}

Once researchers get the kind of trouble damage data group "door", can be viewed insignificant that the trouble "Lever door lever does not return to the position of all" is changed to "alarm door not lock "a drop in the amount of time. Then the researchers make a table for sort of started kind of trouble highest to the lowest kind of trouble in terms of time as a percentage of cumulative here in after created Pareto diagram. In the Pareto diagram later will be visible result of the improvements made. Below is a table of cumulative percentage of the data trouble group "door" after doing repairs.

Table 7: kinds of trouble in the "door"

\begin{tabular}{lllll}
\hline Item Trouble & $\begin{array}{l}\text { Total } \\
\text { (unit in } \\
\text { minute) }\end{array}$ & Percentage & $\begin{array}{l}\text { Cumulative } \\
\text { Percentage }\end{array}$ & $\begin{array}{l}\text { Description } \\
\text { Cumulative } \\
\text { Summation }\end{array}$ \\
\hline $\begin{array}{l}\text { Leave the door cracked and } \\
\text { leaking }\end{array}$ & 272 & $27.53 \%$ & $27.53 \%$ & $27.53 \%$ \\
\hline $\begin{array}{l}\text { Roller plummeted due to } \\
\text { hampered scrap }\end{array}$ & 154 & $15.58 \%$ & $43.11 \%$ & $27.53 \%+15.58 \%$ \\
\hline Alarm Door not lock & 140 & $14.17 \%$ & $57.28 \%$ & \\
\hline Rell doors off & 107 & $10.82 \%$ & $68.10 \%$ & \\
\hline Support locking off the glass & 105 & 10.62 & $78.72 \%$ & \\
\hline $\begin{array}{l}\text { Drag door movement } \\
\text { standstill }\end{array}$ & 95 & $9.61 \%$ & $88.33 \%$ & \\
\hline $\begin{array}{l}\text { Key door didn't get into the } \\
\text { door lock }\end{array}$ & 70 & $7.12 \%$ & $95.45 \%$ & \\
\hline Handle door broken & 45 & $4.55 \%$ & $100.00 \%$ & \\
\hline Total & 988 & $100 \%$ & & \\
\hline
\end{tabular}

Can be seen in the table above kinds of trouble in the "door", that the "alarm door not lock" which originally was "Lever door does not return to its original position", have decline. were originally in the first position, the data in 2014 to third place. To be able to prove it, Researchers then create Pareto diagram, to show that the trouble of groups "door" is "alarm door not lock" has decreased the number of time the occurrence of trouble (time case).

Based on data from the cumulative percentage table above it can be arranged as a Pareto diagram shown in the following figure: 


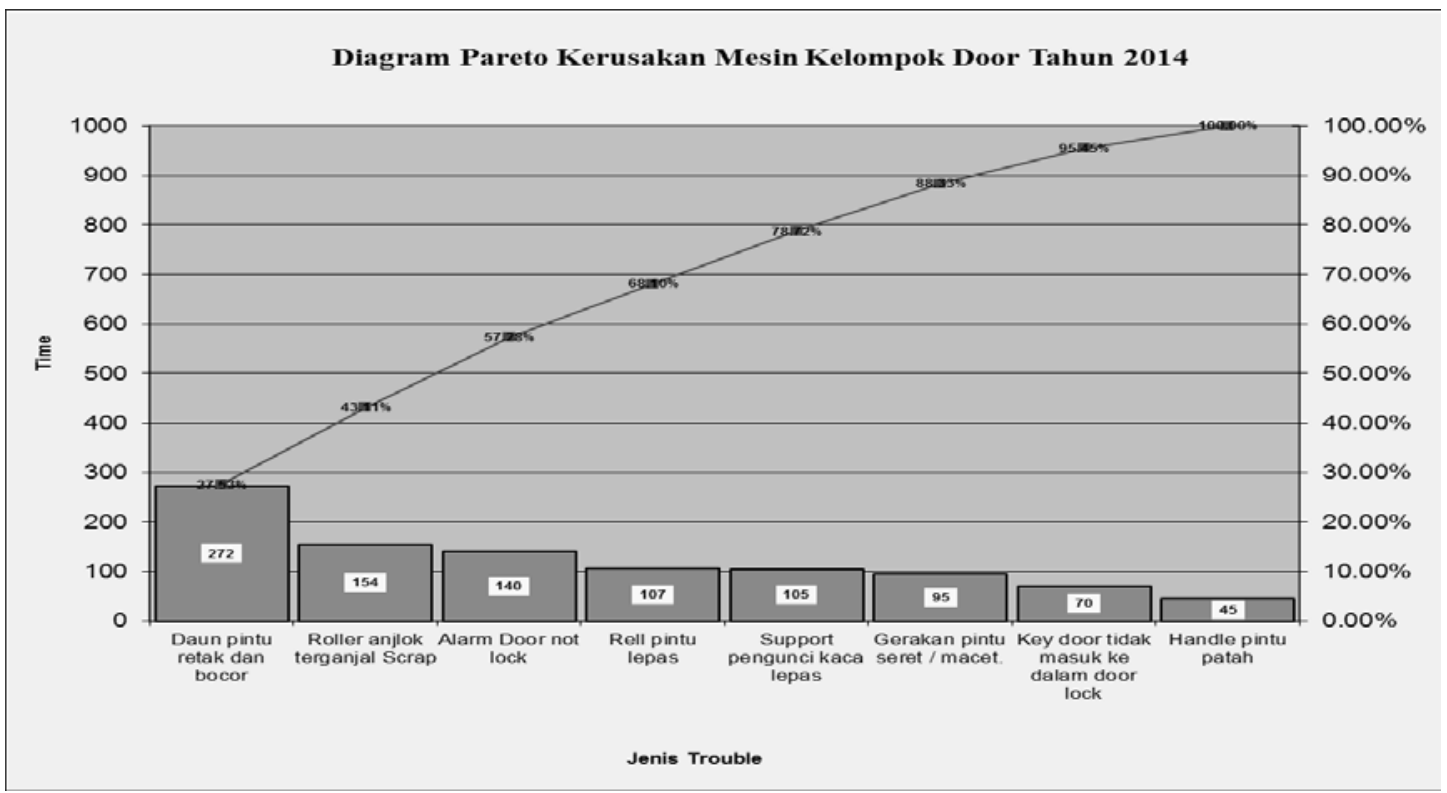

Figure 10: cumulative percentage

Then the researchers also gathered data FANUC robodrill trouble the whole machine is made object of research from January until December 2014, to analyze the comparison before doing repairs after doing repairs. Below is the data FANUC machine damage robodrill period of January till the December, 2014.

Table 8: Unit in minutes

\begin{tabular}{|l|c|c|c|c|c|c|c|c|c|c|c|c|c|}
\hline Item Trouble & Jan & Feb & Mar & Apr & May & Jun & Jul & Aug & Sep & Oct & Nov & Dec & Total \\
\hline Door & $\mathbf{1 1 7}$ & $\mathbf{1 0 6}$ & 95 & 96 & 78 & 51 & 85 & 36 & 85 & 88 & 45 & 106 & 988 \\
\hline Coolant Device & 30 & 20 & 75 & 51 & 0 & 60 & 40 & 70 & 50 & 85 & 20 & 90 & 591 \\
\hline Spindle & 11 & 109 & 180 & 108 & 160 & 60 & 180 & 45 & 25 & 240 & 328 & 305 & 1751 \\
\hline Moving Axis & 0 & 86 & 42 & 0 & 12 & 0 & 100 & 0 & 250 & 300 & 0 & 260 & 1050 \\
\hline Magazine & 65 & 70 & 0 & 30 & 33 & 45 & 0 & 90 & 15 & 50 & 80 & 70 & 548 \\
\hline Control panel & 0 & 0 & 39 & 0 & 0 & 76 & 45 & 0 & 50 & 45 & 0 & 0 & 255 \\
\hline Operating panel & 54 & 150 & 20 & 149 & 50 & 99 & 35 & 150 & 90 & 125 & 90 & 80 & 1092 \\
\hline Pneumatic Device & 0 & 5 & 0 & 0 & 8 & 0 & 5 & 0 & 10 & 0 & 10 & 16 & 54 \\
\hline Other & 10 & 11 & 0 & 20 & 0 & 15 & 43 & 23 & 20 & 5 & 20 & 0 & 167 \\
\hline
\end{tabular}

And the researchers also made a histogram diagram of the overall data engine trouble Fanuc robodrill in 2014, to see the effectiveness of the results of the improvements made. Below is histogram diagram of the overall data trouble occurring in the period January robodrill Fanuc machine until December, 2014. 


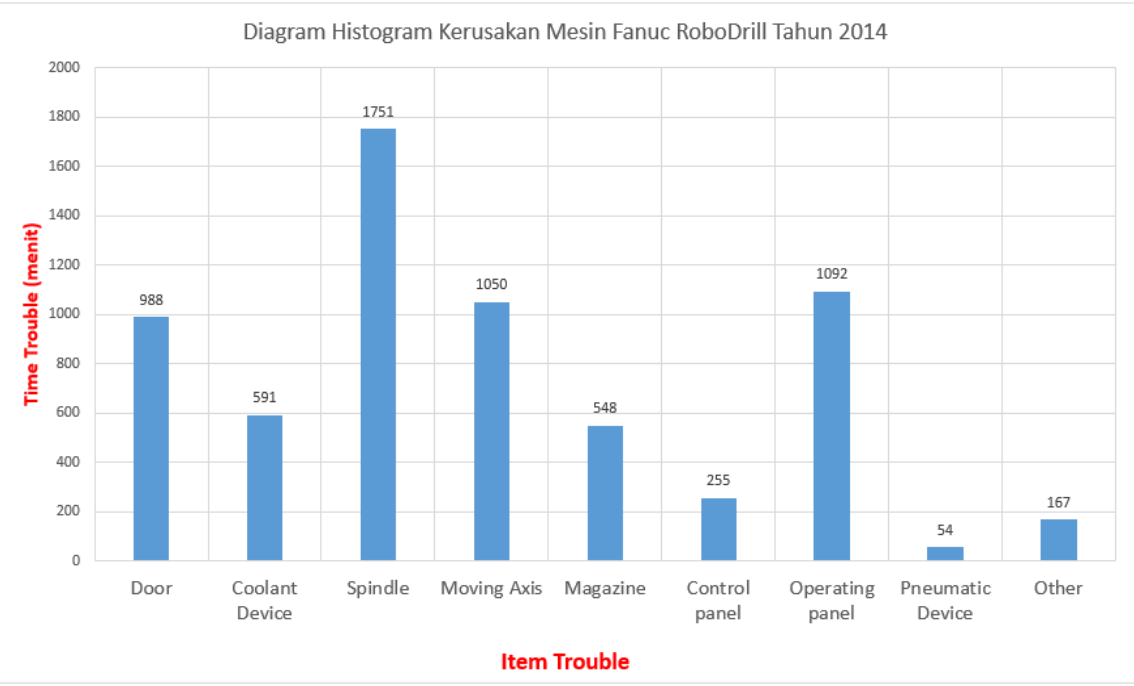

Figure 11: Diagram Histogram Kerusakan Mesin

\subsubsection{Action (Follow-up)}

Step 7 : Standardizing Solutions and Best Practices

After the improvement in the standardization work system robodrill Fanuc machine at the door, to maintain the quality and performance of the machine in order not to decrease and interrupt the production process, it is necessary to periodically checking (Preventive Maintenance).

In this case the researchers create a system of quality checking the door lock cylinder engine that has been Fanuc robodrill do change overall. Researchers create a check sheet for checking part item cylinder lock door for all the machines Fanuc robodrill.

Check sheet serves to know the state part cylinder lock when the machine is operating. And check sheet is useful to know the life time part cylinder lock is used on the machine during operation. Checking performed 1 hour at rest hours work, and within a period of 1 month. Checking also done gradually on each machine, because of the large number of machines Fanuc are made in the object of study, 29 robodrill Fanuc machines.

Step 8: Make Final Report and Determine Next Quality Improvement Plan 
ISSN: 2236-269X

DOI: $10.14807 /$ ijmp.v10i1.590

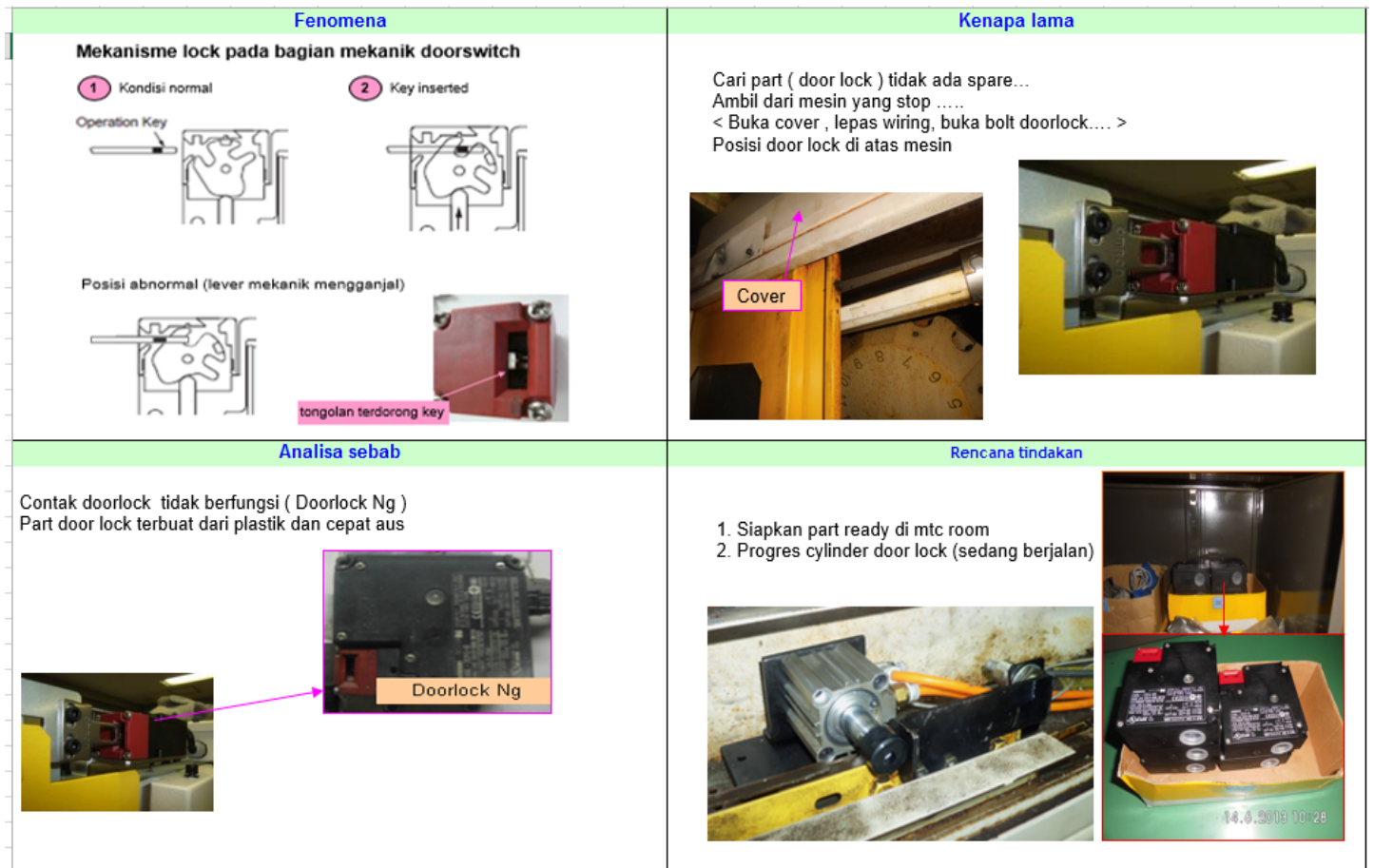

Figure 12: Make Final Report and Determine Next Quality Improvement Plan

\subsection{Recapitulation skill map DELTA maintenance after the implementation of the method in PDCA cycle}

Then from this analytical work, the boss also re-evaluate the skill up performance maintenance after the improvement in the improvement of the group trouble "Door". Following the results of evaluation skills up maintenance machining wheel.

Table 9: Following the results of evaluation skills up maintenance machining

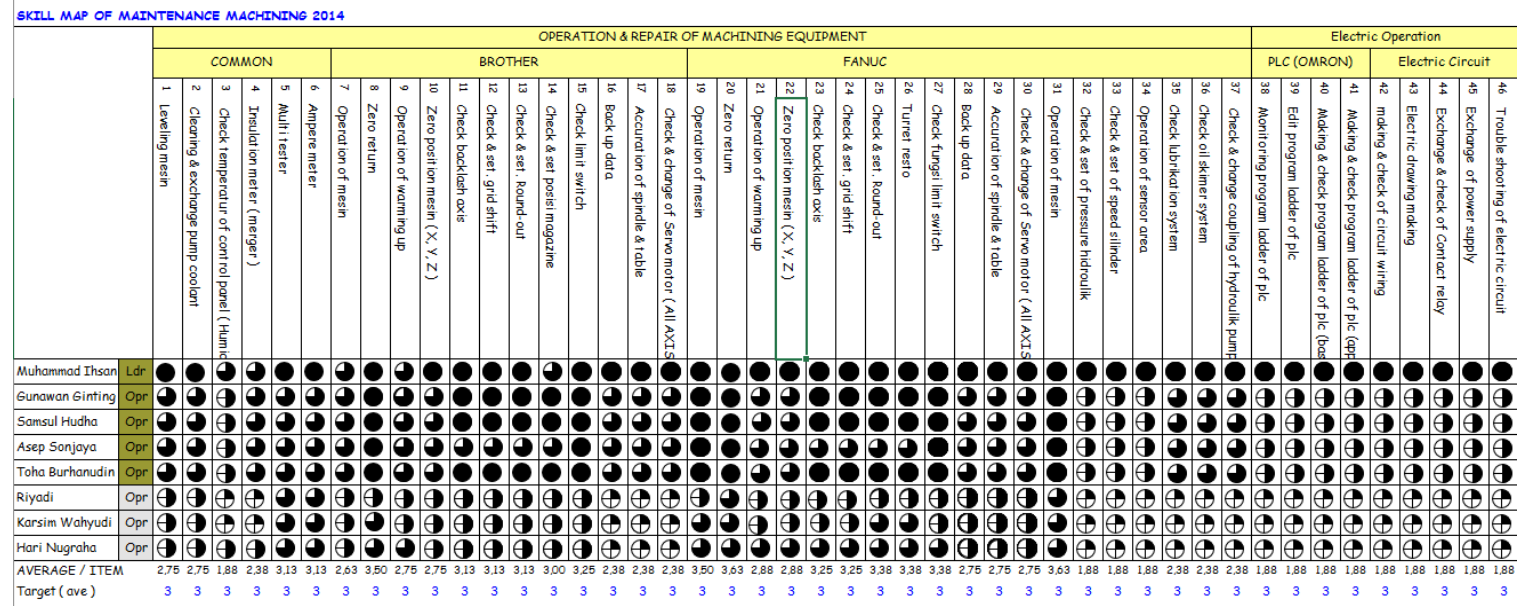

\section{CONCLUSION}

The results showed that the use of PDCA cycle and methods DELTA in analyzing machine damage, very effective and optimal implementation. In addition, 
the applying the philosophy of improvement/kaizen in problem solving skills and make the map as a barometer expertise of each individual maintenance, has a very strong influence on performance improvement.

With the PDCA cycle applied to the methods DELTA done carefully, show that engine damage incurred could be overcome once the root cause is known and specified solutions his best. From the evaluation results of visible achievement of the desired target as well as the positive impact thereof.

Looking at the results of the improvements made by the researcher or the method used in activities repair, the researchers plan to use methods DELTA and the PDCA cycle to implement repair of other types of trouble. We can see from the data and graphs time case Fanuc engine trouble robodrill in the period January to December 2014, there are many kinds of trouble to do structured improvement in handling. In addition to the data obtained and needed to do improvement activities to be accurate, improvements are also becoming more systematic and structured.

\section{REFERENCES}

AL FAKHRI, Faiz. (2010) Analisis Pengendalian Kualitas Produksi Di PT. MASSCOM GRAHPY Dalam Upaya Mengendalikan Tingkat Kerusakan Produk Menggunakan Alat Bantu Statistik. Fakultas Ekonomi Universitas Diponegoro semarang.

ASSAURI, Sofjan. (1998) Manajemen Operasi Dan Produksi . Jakarta : LP FE UI GASPERZ, Vincent. (2005) Total Quality Management. Jakarta: PT. Gramedia Pustaka Utama.

GASPERSZ, Vincent. (2015) Delapan Langkah Tujuh Alat (DELTA) Langkahlangkah Solusi Masalah Kualitas Yang Efektif.

HEIZER, Jay; RENDER, Barry. (2006) Operations Management (Manajemen Operasi). Jakarta: Salemba Empat.

NASUTION, M. N. (2005) Manajemen Mutu Terpadu. Bogor: Ghalia Indonesia. IMAI, M. (2005) Budaya Kaizen. Jakarta: Pustaka Utama.

TAZAKIGROUP, (2000) Budaya Kaizen yang Unik. Jakarta: Gramedia www.tazakigroup.com

PANDUAN 7 Tools, PT. Yamaha Motors Parts Manufacturing Indonesia, Karawang, Jawa Barat

DIREKTORAT JENDERAL INDUSTRI KECIL MENENGAH DEPARTEMEN PERINDUSTRIAN. 2007. Gugus Kendali Mutu (GKM). Jakarta : Di akses 18 januari 2015. 
ISSN: 2236-269X

DOI: 10.14807/ijmp.v10i1.590

KLEEF, Jeroen; ROOIJ, Marcel. (2006) Downtime reduction: A Profitable Road to Success. Canada : Pulp \& Paper Canada, Feb 206; 107,2

WIERSEMA, William H. (2005) Conquering Downtime. Electrical Apparatus;

ProQuest, Dec 2005; 58,12 